\title{
Images, Representations and Heritage
}




\title{
Images, Representations and Heritage
}

\author{
Moving beyond \\ Modern Approaches \\ to Archaeology
}

\section{Edited by \\ Ian Russell}

Department of History

School of Histories and Humanities

Trinity College

Dublin, Ireland

望 Springer 
Editor:

Ian Russell

Department of History

School of Histories and Humanities

Trinity College

Dublin 2

Ireland

russelli@tcd.ie

Library of Congress Control Number: 2006920912

Printed on acid-free paper.

ISBN 10: 0-387-32215-9

ISBN-13: 978-0387-32215-5

e-ISBN: 0-387-32216-7

(C) 2006 Springer Science+Business Media, LLC All rights reserved. This work may not be translated or copied in whole or in part without the written permission of the publisher (Springer Science+Business Media, LLC, 233 Spring Street, New York, NY 10013, USA), except for brief excerpts in connection with reviews or scholarly analysis. Use in connection with any form of information storage and retrieval, electronic adaptation, computer software, or by similar or dissimilar methodology now known or hereafter developed is forbidden. The use in this publication of trade names, trademarks, service marks and similar terms, even if they are not identified as such, is not to be taken as an expression of opinion as to whether or not they are subject to proprietary rights.

Printed in the United States of America.

987665543221

springer.com 


\title{
Foreword
}

\section{SOUVENIR}

\author{
Maev Kennedy \\ The Guardian
}

On my London mantelpiece sit a bone china cup and saucer. They are neither heirlooms, nor a gift, certainly not valuable, nor do I particularly like them - the blue/yellow/purple glaze, the colour of a black eye, is deservedly unusual - but I cannot bear to throw them out. They are views of London, almost certainly made in Germany about a century ago, and transfer printed with Tower Bridge on the saucer and a slightly wonky Trafalgar Square on the cup. They must have been made by the thousand, and I have no doubt there are other black eye tea services out there printed with the Eiffel Tower or the Coliseum. They are cheap mass produced souvenirs, curiously not unlike the sentimental Irish pottery excavated from a New York pit, discussed by Brighton and Orser in chapter two. Mine are neither art objects nor antiques, but they are potent archaeological artefacts.

Archaeology leaves us a grossly distorted illusion of a rounded history: we inherit the temples and graves, the palaces and monuments, as if the world were peopled only by priests, kings and corpses. We market them like cornflakes, or annex their grandeur to contemporary ends of commerce or politics, and in the process risk destroying the monuments, or diminishing them to vanishing point. The fates of the Buddhas of Bamiyan, of the Mostar Bridge, or the ruins of Babylon first rebuilt with bricks stamped to his own glory by Saddam Hussein, then appropriated as an American tank park in the Iraqi war, are mercifully rare. But Stonehenge becomes a snowglobe, the Acropolis an arena where the descendants of the colonised and the colonisers still slug it out, and collectors can pre-order a looted chunk of the temple carvings at Ankor Wat.

Good intentions may be even more damaging, the admirable aim of 'access' leading seemingly inexorably to wide hard surfaced paths gouged across landscapes which are themselves archaeological treasures, 
linking vast new car parks to monuments crumbling under the weight of friendly interest. Warring tribes lay claim to the same fragile spaces, with passionate conviction. I have met, in a small riot on a Summer solstice dawn at Stonehenge, a weeping pagan woman with a terrified child clinging to her skirts, and a few hundred yards away a woman from English Heritage choking back tears. The woman with the child wanted to lay garlands of flowers, the woman from English Heritage was struggling to keep people out of the circle: each was equally convinced of being the one who truly understood, and was therefore charged with protecting, the impassive stones.

Anita Synnestvedt's poetic account, of a very personal encounter with a small monument on a small island in Sweden, was very close to my own first childhood encounters in Ireland, when my father would drive us to some pile of grey stones in a nest of nettles. There was never another soul around, never another car except his current battered ancient black restoration project. There was never any site interpretation, except the occasional rusting green notice proclaiming in Irish that the monument was in the care of the Board of Works. We children were forced, sometimes muttering rebellion and moaning of boredom, to engage our imaginations instead. Many of the contributors to this volume address, directly and indirectly, the problem of what has happened to these monuments and experiences.

Some of those Irish sites now have imposing visitor centres, which give the illusion of answering every question, as well as supplying tea and buns and a triple spiral t-shirt. Similar to Ian Russell's report of how visitors have complained of Stonehenge and the Sphinx at Giza, the monuments themselves seem not enhanced but curiously shriveled. When the visitor finally reaches the object of the heritage pilgrimage, or more often is invited to peer respectfully at it from behind a barricade, it can seem an imposter, less tangible, less real, than the marketed image.

I have experienced the effect myself, when I first visited Malta and the temples I had seen reproduced on countless occasions. They were not, as they appeared when photographed in dramatic silhouette against a setting sun, the size of Abu Simbel, but the size of a reasonably spacious suburban bungalow. They were still magnificent, but there was a moment of wrenching the brain into adapting to the scale. But however well or badly modern man has dealt with the monumental, we have lost track completely of most of the people who have ever shared our earth. Often their very bones are gone, they have left us no more than smears in the 
dirt marking long rotted posts, or the ashes of ancient cooking fires. We poke about in their rubbish dumps searching for the people, the fragments that chipped off a knapped flint, the scraps of hide, the pottery beakers and bronze cauldrons. While the monuments are excavated, interpreted, conserved and displayed, the artefacts seem unmediated, an open line to the past: they seem true. Often, after walking in unthinking admiration through a museum gallery of gold and silver, the clear mark of a thumb on an unadorned pot can stop me in my tracks. If we can see the hollow impression of the thumb, surely we can follow that to the hand, the arm, the shoulder, the head, surely it will lead us to a voice which can answer the eternal question: what was it really like? But artefacts, as much as any other apparent proof, must be interrogated ferociously, treated as hostile witnesses. And often we lack the statement of evidence which will give us the information to ask the right questions. If the cauldron from the Bronze Age rubbish dump has a hole in it, or the knife blade has snapped, is that evidence of ritual killing - or of a worn out piece of kitchen equipment, discarded and replaced?

The history of my cup and saucer is just recoverable to me, but not to most of the people who live on my road. I literally picked them up in the gutter of the small suburban road where I live, along with a disintegrating cardboard box full of equally banal bits and pieces, which were clearly the once treasured contents of a very modest china cabinet. However, the Edwardian flats that once were the home to these objects are now so expensive that they are almost all bought by young professional couples, who will both have to work forever to cover the mortgage - or sell, and move on and up to an even larger mortgage, the instant that property inflation means they have some equity. As the older residents die, the road is gradually being scoured of its previous history. The houses were built as flats for rent, in the first decades of the 20th century, after the railway arrived and a small village among cabbage fields became a suburb. The flats were built with two flats to each house, each flat with its own hall door, and between every two houses there was an outdoor lavatory, and a wash house with a copper. When I came first, the oldest residents, a handful who remembered moving into the new houses, many born in the flats, told me such lavish facilities, shared between only four households, were regarded with awe. Now the thousands of children who were born into the 96 flats are scattered around the world. The remaining men die first, and when I moved in about a third of flats were inhabited by one very elderly lady, living 
alone. One near me was talking on the phone to her great friend, a street away but no longer visitable, when there was a crash and she was able to explain, quite calmly, that the hall ceiling had collapsed on her. In the years since I moved in, the passing of each ancient lady has been marked by an unchanging ritual. The Polish contractors arrive in a white van, and stay for about a week. They work hard, fast and well, and when they leave the flat has been emptied and cleansed of all original fittings and a century of wallpaper, back to the bare boards and the replastered white painted walls. The sale board appears in the garden the following day.

My box had been dumped by one such gang. I had already seen the empty china cabinet in a skip. People do not keep such shrines for household gods now, and there is no resale market for these old fashioned pieces of cheap furniture. I could no more leave the sodden box in the gutter, waiting for the refuse collectors, than I could have passed a crate of abandoned puppies. I kept the silver plate sugar bowl and cream jug, which were stamped with the name of a good solid expensive shop and must have been wedding presents, and I found good homes for all the other pieces, as I would have for puppies. Nobody I know would have given shelf space to the cup and saucer, but they speak to me of a lost age, a time of aspiration and optimism, when the half hour train journey to central London, my much cursed daily commute, was a rare enough treat to be worth bringing home a souvenir.

The white vans call less often now. The little old ladies are almost all gone. Most of the new couples will never have met anyone who can tell them the modest history of a very ordinary suburban street. I had never written it down - until now - so if my cup and saucer turns up in 500 years in a rubble of Edwardian bricks, what answers will they give? It might well be assumed that the cup and saucer are not only mine in the sense of something chosen and bought by me, but worse, that they are representative objects of a type in common daily use. An entire lost dinner service may be posited, Tower of London soup bowls, Buckingham Palace tea pot. A patriotic pride in these places may be inferred, which is in fact entirely lacking in this Irish Roman Catholic economic migrant. If the archaeologist asks the wrong questions, an entirely plausible and entirely false society could be built on the foundations of my cup and slightly cracked saucer.

This volume kicks up far more questions than answers, and from a much wider community than those usually invited to join the debate. This is absolutely proper. The illusion of certainty has done great harm to 
archaeology. If there is a moral, it is to ask questions: question the monuments, question the artefacts, and above all, question relentlessly and with unwavering suspicion anyone who claims to have the one true answer. 


\section{Acknowledgements}

I would like to thank Teresa Krauss for her enthusiasm and belief in this project, without whose dedication this project would not have occurred. I would also like to thank the secretariat of the European Association of Archaeologists for allowing the original session from which this volume developed to take place at Lyon 2004. I am indebted to Deirdre Stritch and Andrew Cochrane for helping copy-edit this volume. Thank you to Christine Riffle for her assistance in the formatting and production of the manuscript. I would also like to thank General Services Administration and John Milner Associates for granting permission to reproduce photographs of the pearlware and whiteware teacups in Chapter 2, Wilfried Beege for granting permission to use his photograph published in the German women's magazine Verena in Chapter 6, the Polo Museale Fiorentino for granting permission to reproduce 'Il Duca e la Duchessa di Urbino' painted by Piero della Francesca in Chapter 10, the National Museum of Denmark for granting permission to reproduce photographs taken by Lennart Larsen of bog bodies in Chapter 11 and Kathleen Vaughan for granting permission to reproduce photographs of her art work in Chapter 11. A special thanks to Maev Kennedy for giving her professional support to the volume and for providing such an engaging foreword. I would also like to thank Prof. Terry Barry and Dr Hazel Dodge for their continuing mentorship, guidance and support. I would also like to express my gratitude to Harriet McCollum, Dr John A. Russell, Clare Trow, Sarah Ling, Matthew Torney and Killian McAleese for their continuing encouragement, belief and support. Finally, I wish to say thank you to all the contributors to this volume for being so very flexible and adventurous, partaking in what I feel has been a tremendous period of exchange and philosophical development.

-Ian Russell, January 2006 


\section{Contents}

\section{IMAGES, REPRESENTATIONS AND HERITAGE}

Moving beyond Modern Approaches to Archaeology

Foreword: Souvenir $\quad$ v-ix

Maev Kennedy

Acknowledgements xi

Table of Contents xiii-xv

List of Illustrations and Tables xvii-xix

List of Contributors xxi-xxiii

Introductions: Images of the Past: Archaeologies, Modernities, 1

Crises and Poetics

Ian Russell

\section{SECTION I \\ 'ARCHAEOLOGICALLY IMAGINED COMMUNITIES'}

Introduction

Ian Russell

1: Archaeological Tourism: A Signpost to National Identity Deirdre Stritch

2: Irish Images on English Goods in the American Market

The Materialization of a Modern Irish Heritage

Stephen A. Brighton \& Charles E. Orser, Jr.

3: Representing Spirit: Heathenry, New-Indigenes and the

Imaged Past

Jenny Blain \& Robert J. Wallis

$\underline{\text { Responses }}$

Deirdre Stritch, Stephan A. Brighton, Charles E. Orser, Jr., Jenny Blain \& Robert J. Wallis 


\section{SECTION II \\ ARCHAEOLOGIES AND OPPORTUNITIES}

Introduction

Ian Russell

4: The Role of Archaeology in Presenting the Past to the Public George S. Smith

5: Assessing the Role of Digital Technologies for the

Development of Cultural Resources as Socio-economic Assets

Oleg Missikoff

6: Experiencing Archaeology in the Dream Society

Cornelius Holtorf

$\underline{\text { Responses }}$

George S. Smith, Oleg Missikoff \& Cornelius Holtorf

\section{SECTION III \\ THE 'CRISIS OF REPRESENTATION' OF THE PAST}

Introduction

Ian Russell

7: Towards Archaeologies of Memories of the Past and Planning 187 Futures: Engaging the Faustian Bargain of 'Crises of Interpretation' Stephanie Koerner

8: Collective Memory and the Museum: Towards a Reconciliation 221 of Philosophy, History and Memory in Daniel Libeskind's

Jewish Museum

Kay F. Edge \& Frank H. Weiner

9: The Simulacra and Simulations of Irish Neolithic

Passage Tombs

Andrew Cochrane 
$\underline{\text { Responses }}$

Stephanie Koerner, Kay F. Edge, Frank H. Weiner

\& Andrew Cochrane

\section{SECTION IV \\ POETIC ARCHAEOLOGIES AND MOVING BEYOND \\ MODERNITY}

Introduction

Ian Russell

10: Practice Makes Perfect: A Discussion of the Place of the Brochure Image in Landscape Tourism

Tim Neal

11: Bog Bodies and Bog Lands: Trophies of Science, Art and the Imagination

Christine A. Finn

12: Who Wants to Visit a Cultural Heritage Site? A Walk through an Archaeological Site with a Visual and Bodily Experience Anita Synnestvedt

$\underline{\text { Responses }}$

Tim Neal, Christine A. Finn \& Anita Synnestvedt

Concluding Remarks: Imagining the Past: Moving beyond

Modern Approaches to Archaeology

Ian Russell

Index 


\section{Illustrations and Tables}

2-1 Blue transfer-printed pearlware teacup and saucer with the image of Lady Hibernia and accompanying symbols of the shamrock and oak leaves and acorns.

2-2 Brown transfer-printed whiteware teacup with the image of Father Mathew.

2-3 Interior of the Father Mathew cup.

3-1 Replica in pewter of an 11th century CE pendant interpreted as a Thor's Hammer from Rømersdal on Bornholm, Denmark.

3-2 Heathen shaman 'Runic John' performs a shamanic healing.

3-3 Silver replica of an artefact often interpreted as an image of the goddess Freyja wearing the necklace Brisingamen, 9th century CE, Aska in Östergötland, Sweden.

3-4 Modern bronze pendant usually understood to be a Valkyrie, based on a 9th-10th century CE silver pendant from Öland, Sweden.

3-5 Effigies of the runes Ing and Daeg are burnt in a celebration of fertility and of the earth at a Spring festival in the South of England.

3-6 Smoky quartz crystal ball and yew-wood runes. Such spheres are used in ritual practice by some heathens, drawing on finds of Anglo-Saxon crystal balls in the archaeological record

3-7 Chalk spiral markings in the Neolithic tomb of West Kennet Long Barrow, Avebury.

3-8 Chalk 'art' in West Kennet Long Barrow. 106

5-1 Domains of creative activity. 143

5-2 Euro-Creativity Trend Index and GDP Growth 1995-9. 144

5-3 Worldwide export earnings. 147

5-4 GDP vs International Tourist Arrivals. 147

5-5 Life-cycle of a digital/virtual cultural resource. 151

6-1 Image from the German women's magazine Verena. 164

8-1 Exterior, view of existing museum and Jewish Museum Extension. 
8-2 Exterior, view of Jewish Museum Extension with existing museum beyond. $\quad 230$

8-3 Exterior, detail view of wall with parapet and windows. 231

8-4 Exterior, detail view of exterior wall with opening. 231

8-5 Interior, view of concrete beams above stair. 232

8-6 Interior, view of Holocaust Tower with air vents. 233

8-7 Interior, view of Holocaust Tower ceiling. 233

8-8 Exterior, view of Peace garden with Jewish Museum Extension beyond. 234

9-1 The Boyne Valley passage tombs nearest the Visitor Centre.

9-2 Knowth Site 1 during reconstruction, with sheep on 'watching-brief'.

9-3 (a) Profile of the cairn slip in front of K95 during excavation. (b) the reconstructed quartz façade at Newgrange Site 1 as seen today.

9-4 (pre)fabricated material culture display in the Visitor Centre.

9-5 K52 at Newgrange Site 1 seen as one complete composition in two different mediums.

9-6 Succession of overlays on Orthostat 48 (Or. 48), eastern tomb, Knowth 1.

9-7 Succession of overlays on Orthostat 45 (Or. 45), western tomb, Knowth 1

10-1 Villa and Gardens of Cetinale, near Siena. 304

10-2 Tourists looking at San Gimignano, Tuscany. 304

10-3 The Duke of Urbino from 'Il Duca e la Duchessa di Urbino' painted by Piero della Francesca.

10-4 Looking over Florence from the top of the Boboli Gardens. $\quad 305$

10-5 Clearance cairns on hillside outside San Gimigniano. 307

10-6 The 'Haha!' by jaYxa as part of 'Province' an exhibition at the Mappin Gallery, Sheffield. 309

10-7 Lorry containers above the road near Genova. 312

11-1 Tollund Man. 316

11-2 Tollund Man - head. $\quad 317$

11-3 Grauballe Man. 318

11-4 Kathleen Vaughan - Bog Series 3 (1996). 324

11-5 Kathleen Vaughan - Bog Fragment 7: 
The Touch of You (1996) (outside).

11-6 Kathleen Vaughan - Bog Fragment 7:

The Touch of You (1996) (inside).

11-7 Kathleen Vaughan - Bog Fragment 7:

The Touch of You (1996) (close up).

12-1 The Bronze Age Cairn at 'Stora Rös'.

12-2 The seamark on top of the former bunkers at the site 'Stora Rös'.

12-3 The restored cairn with its little fence around at the site 'Stora Rös'.

12-4 The 'manmade' mountain with its peculiar surface. 342

12-5 Seagulls meeting by the landmark at the site 'Stora Rös'. 342

12-6 A present use of the site; the nearby school has an athletic day and uses the site 'Stora Rös' as a place for the youths to do press-ups.

12-7 A present use of the site 'Stora Rös': a wedding performed at the place in July 2004.

12-8 Being 'on top' of the world at 'Stora Rös'.

\section{TABLES}

2-1 Number of Land Holdings in 1845 . 66

5-1 The components of Florida's '3Ts' model. 145

5-2 Key elements of the European Area of digitised cultural (re)sources Ontologies and the Semantic Web. 154

7-1 Systems of supposed synonymous dichotomies. 


\section{Contributors}

\section{Jenny Blain}

Programme Leader, MA Social Science Research Methods, Applied Social Science, Faculty of Development and Society, Sheffield Hallam University, Collegiate Crescent Campus, Sheffield, S10 2BP, UK

j.blain@shu.ac.uk

\section{Stephen A. Brighton}

Assistant Professor, 0132 Woods Hall, Department of Anthropology, University of Maryland, College Park, MD 20742, USA sbrighton@anth.umd.edu

\section{Andrew Cochrane}

School of History and Archeology, Cardiff University, Humanities Building, Colum Drive, Cardiff, CF10 3EU, UK cochranea@cf.ac.uk

\section{Kay Edge}

School of Architecture + Design, College of Architecture and Urban Studies, 201 Cowgill Hall, Virginia Polytechnic Institute and State University, Blacksburg, Virginia 24061, USA kedge@vt.edu

\section{Christine A. Finn}

Visiting Fellow, Department of Archaeology and Anthropology, University of Bristol, Old Baptist College, 43 Woodland Road, Clifton, Bristol BS8 1UU, UK

christine.finn@gmail.com

\section{Cornelius Holtorf}

Lunds Universitet, Institutionen för Arkeologi och Antikens Historia, Box 117, 22100 Lund, Sweden cornelius.holtorf@ark.lu.se 


\section{Maev Kennedy}

Archaeology Correspondent, The Guardian, 119 Farringdon Road, London EC1R 3ER, UK

maev.kennedy@guardian.co.uk

\section{Stephanie Koerner}

School of Art History and Archaeology, University of Manchester, Oxford Road, Manchester M13 9PL, UK stephanie.koerner@man.ac.uk

\section{Oleg Missikoff}

Via di Vigna Filonardi 7, 00197 - Rome, Italy

omissikoff@luiss.it

\section{Tim Neal}

Department of Town and Regional Planning, University of Sheffield, Winter Street, Sheffield S3 7ND, UK tim.neal@shef.ac.uk

\section{Charles E. Orser, Jr.}

Center for the Study of Rural Ireland, Illinois State University, Campus Box 4660, Normal, IL 61790-4660, USA

ceorser@ilstu.edu

\section{Ian Russell}

Department of History, School of Histories and Humanities, Trinity College, Dublin 2, Ireland russelli@tcd.ie

\section{George S. Smith}

Associate Director, Southeast Archeological Center, 2035 East Paul Dirac Dr., Johnson Building, Suite 120, Tallahassee, FL 32310, USA george_s_smith@nps.gov 


\section{Deirdre Stritch}

Department of Classics, School of Histories and Humanities, Trinity College, Dublin 2, Ireland deirdre.stritch@gmail.com

\section{Anita Synnestvedt}

Department of Archaeology, Göteborg University Olof Wijksgatan 6, Box 200, S-405 30 Göteborg, Sweden anita.synnestvedt@archaeology.gu.se

\section{Robert J. Wallis}

Associate Professor of Visual Culture and Associate Director, MA in Art History, Richmond the American International University in London, 1 St Alban's Grove, Kensington, London W8 5PN, UK wallisr@Richmond.ac.uk

\section{Frank H. Weiner}

Associate Professor, School of Architecture + Design, College of Architecture and Urban Studies, 201 Cowgill Hall, Virginia Polytechnic Institute and State University, Blacksburg, Virginia 24061, USA fweiner@vt.edu 